Check for updates

Cite this: RSC Adv., 2019, 9, 15836

Received 13th February 2019

Accepted 9th May 2019

DOI: $10.1039 / \mathrm{c} 9 \mathrm{ra01127g}$

rsc.li/rsc-advances

\title{
Synthesis of $\left(\mathrm{Bi}_{1-x} \mathrm{Sb}_{x}\right)_{2} \mathrm{~S}_{3}$ solid solutions via thermal decomposition of bismuth and antimony piperidinedithiocarbamates $\uparrow$
}

Walter N. Kun, (D) ab Paul D. McNaughter, (D) ${ }^{\mathrm{b}}$ Linda D. Nyamen, ${ }^{a}$ Ben F. Spencer, (D) Paul O'Brien, (iD bc Peter T. Ndifon*a and Neerish Revaprasadu (iD *d

\begin{abstract}
The synthesis of the complete range of $\left(\mathrm{Bi}_{1-x} \mathrm{Sb}_{x}\right)_{2} \mathrm{~S}_{3}$ solid solutions, where $0 \leq x \leq 1$, by the variation of the mole ratio of bismuth and antimony piperidine dithiocarbamate complexes is reported. There was a near linear expansion of $a$ and $c$ lattice parameters as the mole ratio of the antimony precursor was increased. The composition of the particles directionally followed the amount of precursor ratio used. When the composition of particles was compared to cell parameters, a slight deviation from Vegard's law was observed with a corresponding contraction of the $b$ parameter and an approximately $3.5 \%$ reduction of the lattice volume. The nanorods obtained showed aspect ratios that depend on the composition of the material. The $\mathrm{Bi}$ and $\mathrm{Sb}$ rich materials had high aspect ratios of 16.58 and 16.58 respectively with a minimum aspect ratio of 2.58 observed for $x=0.50$.
\end{abstract}

\section{Introduction}

The composition, size, shape and surface topography play important roles in the performance of electronic, optoelectronic, and energy devices. ${ }^{1}$ The incorporation of a foreign atom or ion into a host crystal lattice of a semiconductor material can introduce new functional properties. ${ }^{2-4}$ Group V-VI compounds have attracted much attention due to their earth abundance and environmentally friendly nature. They display many important properties suitable for optoelectronic applications. ${ }^{1,5-8} \mathrm{Bi}_{2} \mathrm{~S}_{3}$ has a direct band gap between $1.30 \mathrm{eV}$ and $1.70 \mathrm{eV}$ close to the optimal band gap for terrestrial solar cell energy conversion and a high energy conversion efficiency $\left(\geq 10^{5} \mathrm{~cm}^{-1}\right)$ and as such, is widely used for photovoltaic materials and photodiode arrays. ${ }^{9-13} \mathrm{Sb}_{2} \mathrm{~S}_{3}$ has an energy band gap between $1.78 \mathrm{eV}$ and $2.50 \mathrm{eV}$ covering the visible and the near infrared region of the electromagnetic spectrum and shows good photovoltaic properties. ${ }^{14,15}$ It has found use in thermoelectric devices, write once and read many (WORM) optical storage devices, IR region television cameras, infrared spectroscopy and in lithium/

\footnotetext{
${ }^{a}$ Department of Inorganic Chemistry, University of Yaoundé, I. P. O. Box 812, Yaoundé, Cameroon

${ }^{b}$ School of Materials, University of Manchester, Oxford Road, Manchester, M13 9PL, UK

${ }^{c}$ Schools of Chemistry and Materials, University of Manchester, Oxford Road, Manchester, M13 9PL, UK

${ }^{d}$ Department of Chemistry, University of Zululand, Private Bag X1001, KwaDlangezwa, 3886 South Africa. E-mail: RevaprasaduN@unizulu.ac.za

$\dagger$ Electronic supplementary information (ESI) available. CCDC 1889653. For ESI and crystallographic data in CIF or other electronic format see DOI: 10.1039/c9ra01127g
}

sodium ion batteries. ${ }^{16-22}$ solar cells based on $\mathrm{Sb}_{2} \mathrm{~S}_{3}$ films have been fabricated with power conversion efficiency of $4.3 \%{ }^{23,24}$

Despite the significant difference in their sizes $\mathrm{Bi}$ and $\mathrm{Sb}$ form a full range solid solution series between stibnite and bismuthinite. ${ }^{25,26}$ The formation of a solid solution between the two compounds is due to their similarity in charge, ability to crystallize in the same orthorhombic lattice with space group Pnma, having typical lattice parameters of $a=11.2690 \AA, b=$ $3.9717 \AA$ and $c=11.1290 \AA$ for bismuthinite and $a=11.2990 \AA$, $b=3.8313 \AA$ and $c=11.2270 \AA$ for stibnite. ${ }^{27,28}$ Their orthorhombic unit cell volume differs by $3.5 \%{ }^{29-32}$ Analysis on various stibnite and bismuthinite samples from various localities show that replacement of Sb with Bi goes up to 55 moles\% giving a limiting mixability range of $\left(\mathrm{Bi}_{0.45} \mathrm{Sb}_{0.55}\right)_{2} \mathrm{~S}_{3}$ in naturally occurring $\mathrm{Bi}_{2} \mathrm{~S}_{3}-\mathrm{Sb}_{2} \mathrm{~S}_{3}$ solid solution. ${ }^{25,32,33}$ This paucity of representation covering the whole solid solution range in natural samples is attributed to the different geological conditions under which bismuthinite and stibnite are deposited in nature. ${ }^{25,34}$ Kyono et al. synthesised a full range $(\mathrm{BiSb})_{2} \mathrm{~S}_{3}$ solid solution series with a nearly statistical substitution of $\mathrm{Sb}$ for bismuth by heating $\mathrm{Bi}_{2} \mathrm{~S}_{3}$ and $\mathrm{Sb}_{2} \mathrm{~S}_{3}$ at 800 to $1000{ }^{\circ} \mathrm{C} .{ }^{30}$ However, their method provided no control over stoichiometry as four samples with the same composition range were obtained from a starting mixture with the same $\mathrm{Bi}_{2} \mathrm{~S}_{3}: \mathrm{Sb}_{2} \mathrm{~S}_{3}$ molar ratio. This observation of large deviations from linear trends in the lattice constants was in contradiction to earlier work by Nayak et al. that showed good agreement with Vegard's law on the entire solid solution range by depositing thin films of the solid solution by a dip-dry method. ${ }^{10}$ Colloidal synthesis of nanostructures in surface passivating agents has proven to be an efficient route as it provides easy control over size and 
shape. ${ }^{35,36}$ Wang et al. used a dual precursor source route to synthesize a full range solid solution of $\left(\mathrm{Bi}_{1-x} \mathrm{Sb}_{x}\right)_{2} \mathrm{~S}_{3}$ with aspect ratios that depended on their compositions. ${ }^{1}$ Patra et al. did similar work using diethyldithiocarbamate complexes in oleylamine and thiol. ${ }^{4}$ However, they did not investigate the influence of the Sb substitution on the lattice constant. ${ }^{37}$ Khan et al. prepared the entire range of $\left(\mathrm{SnS}_{1-x} \mathrm{Se}_{x}\right)$ from bis(selonobenzoato)dibutyltin(Iv) and bis(thiobenzoato)-dibutyltin(Iv) complexes by colloidal and melt methods and showed that the colloidal method provided superior control over composition, though both methods showed compositional dependence in the variation of the lattice parameters. ${ }^{38}$ In our earlier work, we showed that addition of a small amount of dodecanethiol was efficient in directing the shapes of $\mathrm{Bi}_{2} \mathrm{~S}_{3}$ rods from single source precursors by thermal decomposition of bismuth dithiocarbamate complexes in high boiling point coordination solvents. ${ }^{39}$

This paper examines the effect of substituting antimony for bismuth on the structure of the bismuthinite-stibnite solid solution prepared by bismuth piperidine and antimony piperidine dithiocarbamate complexes.

\section{Experimental section}

Bismuth trichloride (98\%, Sigma-Aldrich), antimony trichloride (99\%, Sigma-Aldrich), carbon disulphide (99.9\%, SigmaAldrich), piperidine (99.5\% Sigma-Aldrich), oleylamine (98\% Sigma-Aldrich), 1-dodecanethiol (98\% Sigma-Aldrich), ethanol (99.8\% Sigma-Aldrich), chloroform (99.8\% Sigma-Aldrich), chloroform-d (99.8\% Sigma-Aldrich), and sodium hydroxide (97\% Fisher Scientific) were used as supplied without further purification.

\section{Synthesis of the precursors}

Preparation sodium piperidine dithiocarbamate (1). The synthesis of (1) followed previously reported procedure with modifications. $^{39}$ In a typical synthesis, carbon disulfide $(0.1 \mathrm{~mol}, 6.0 \mathrm{~mL})$ was added to an equimolar mixture of sodium hydroxide (0.1 mol, $4.0 \mathrm{~g}$ ) and piperidine (0.1 mol, $9.9 \mathrm{~mL})$ cooled to $0{ }^{\circ} \mathrm{C}$. After $15 \mathrm{~min}$, the white precipitate formed was filtered, dried in air and recrystallised from acetone/petroleum ether. $\mathrm{Na}\left(\mathrm{S}_{2} \mathrm{CPip}\right)$ : yield: $92 \% / \mathrm{mp} 295{ }^{\circ} \mathrm{C}$. Significant IR bands: $\nu$ $=3377(\mathrm{O}-\mathrm{H}), 964(\mathrm{C}=\mathrm{S}), 1468 \mathrm{~cm}^{-1}(\mathrm{C}=\mathrm{N})$; elemental analysis (\%) for $\mathrm{C}_{6} \mathrm{H}_{14} \mathrm{NS}_{2} \mathrm{O}_{2} \mathrm{Na}$ : C 32.86, $\mathrm{H}$ 6.43, N 6.39, Na 10.48, $\mathrm{S}$ 29.24; found: C 33.05, H 6.34, N 6.6.33, Na 10.66, S 28.88.

Preparation of tris(piperidindithiocarbamato)bismuth(III) (2). The synthesis of (2) followed our previous procedure with modifications. ${ }^{37} \mathrm{BiCl}_{3}$ (5.0 mmol, $1.58 \mathrm{~g}$ ) was suspended in ethanol $(15.0 \mathrm{~mL})$, and added dropwise to a solution of the piperidine dithiocarbamate ligand $(15.0 \mathrm{mmol}, 2.75 \mathrm{~g})$ in ethanol $(25.0 \mathrm{~mL})$ followed by stirring for $1 \mathrm{~h}$. The yellow precipitate formed was collected by filtration and recrystallized from chloroform. $\mathrm{Bi}(\mathrm{PipDtc})_{3} \cdot \mathrm{H}_{2} \mathrm{O}$ : yield $89 \% \mathrm{mp} 230{ }^{\circ} \mathrm{C}$. Significant IR bands: $\nu=3477(\mathrm{O}-\mathrm{H}), 967(\mathrm{C}=\mathrm{S}), 1468 \mathrm{~cm}^{-1}$ $(\mathrm{C}=\mathrm{N})$; elemental analysis (\%) for $\mathrm{C}_{18} \mathrm{H}_{32} \mathrm{~N}_{3} \mathrm{OS}{ }_{6} \mathrm{Bi}$; calc; $\mathrm{C} 30.54$, H 4.56, N 5.94, S 27.18, Bi 29.52. Found; C 30.99, H 4.28, N 5.98, S 26.80, Bi 29.39.
Preparation of tris(piperidindithiocarbamato)antimony(III) (3). The procedure for (3) was the same as (2) with some modifications. $\mathrm{SbCl}_{3}(5.0 \mathrm{mmol}, 1.14 \mathrm{~g})$ was suspended in ethanol $(15.0 \mathrm{~mL})$ and added dropwise to a solution of the piperidine dithiocarbamate ligand (15.0 mmol, $2.75 \mathrm{~g})$ in ethanol $(25.0 \mathrm{~mL})$. The resultant solution was stirred for $1 \mathrm{~h}$. The pale-yellow precipitate formed was collected by filtration and recrystallized from chloroform.

$\mathrm{Sb}(\mathrm{PipDtc})_{3} \cdot 3 \mathrm{H}_{2} \mathrm{O}$ : yield $82 \% \mathrm{mp} 239{ }^{\circ} \mathrm{C}$. Significant IR bands: $\nu=3377(\mathrm{O}-\mathrm{H}), 967(\mathrm{C}=\mathrm{S}), 1476 \mathrm{~cm}^{-1}(\mathrm{C}=\mathrm{N})$; elemental analysis (\%) for $\mathrm{C}_{18} \mathrm{H}_{36} \mathrm{~N}_{3} \mathrm{O}_{3} \mathrm{~S}_{6} \mathrm{Sb}$; calc; $\mathrm{C} 32.92, \mathrm{H} \mathrm{5.53,} \mathrm{N} \mathrm{6.40,} \mathrm{S}$ 29.30, Sb 18.54. Found; C 32.72, H 5.84, N 6.47, S 30.14, Sb 19.15.

\section{Synthesis of $\left(\mathrm{Bi}_{x} \mathrm{Sb}_{1-x}\right)_{2} \mathrm{~S}_{3}$ solid solutions}

$\left(\mathrm{Bi}_{x} \mathrm{Sb}_{1-x}\right)_{2} \mathrm{~S}_{3}$ solid solutions were prepared by variation of the mole ratio of (2) and (3). In a typical experiment, a mixture of (2) and (3) totalling $0.29 \mathrm{mmol}$ was dispersed in a mixture of oleylamine $(4.0 \mathrm{~mL})$ and 1-dodecanethiol $(0.2 \mathrm{~mL})$. This was injected into $8.0 \mathrm{~mL}$ of hot oleylamine $\left(230{ }^{\circ} \mathrm{C}\right)$ under $\mathrm{N}_{2}$. After $30 \mathrm{~min}$ the reaction was quenched, and the ensuing black precipitate washed three times with ethanol $(12.0 \mathrm{~mL})$, centrifuged $(11000 \mathrm{rpm})$ and dispersed in toluene $(5.0 \mathrm{~mL})$.

\section{Instrumentation}

Fourier transform infrared spectroscopy was performed using a Thermo Scientific Nicolet iS5 instrument (4000-400 $\mathrm{cm}^{-1}$, resolution $4 \mathrm{~cm}^{-1}$ ). Optical measurements were performed on a Shimadzu UV-1800 spectrophotometer. Elemental analysis was performed with a Thermo Flash 2000 and Carlo Erba EA 1108 elemental analysers (Department of Chemistry University of Manchester). Melting points were recorded on a Stuart SMP10 Melting point apparatus. Thermogravimetric analysis was performed on a Seiko SSC5200/S220TG/DTA model, at a heating rate of $10{ }^{\circ} \mathrm{C} \min ^{-1}$ from $30{ }^{\circ} \mathrm{C}$ to $600{ }^{\circ} \mathrm{C}$, under nitrogen.

XRD patterns of the thin films were collected on a PANalytical X'Pert PRO powder diffractometer (Material Science University of Manchester) with a $\mathrm{Cu} \mathrm{K} \alpha$ radiation source $(\lambda=$ $1.5406 \AA$ ). The samples were mounted flat and scanned over the $2 \theta$ range of $10-70^{\circ}$ in a step size of 0.05 .

X-ray photoelectron spectroscopy (XPS) was performed using an Axis Ultra Hybrid (Kratos Analytical, United Kingdom) using $10 \mathrm{~mA}$ emission $(150 \mathrm{~W})$ of monochromated $\mathrm{Al} \mathrm{K} \alpha$ radiation (1486.6 eV). Samples were pressed onto carbon tape, and a charge neutraliser was used to replenish electrons at the surface and remove the effects of differential charging under the X-ray beam. High resolution spectra were collected using an electron energy analyser pass energy of $20 \mathrm{eV}$ and survey spectra with $80 \mathrm{eV}$ pass energy.

X-ray photoelectron spectroscopy (XPS) data were analysed using CASAXPS (www.casaxps.com): the binding energy scales were calibrated using the principle $\mathrm{C}$ 1s peak associated with hydrocarbon at $284.8 \mathrm{eV}$, Shirley backgrounds were fitted where appropriate, and atomic concentrations were calculated using relative sensitivity factors incorporating the photoionization 
cross section for each core electron orbital, as well as the transmission function of the electron energy analyser. Peak fitting using Voigt-approximation Gaussian-Lorentzian products was performed to obtain binding energy positions for chemical species determination.

Transmission electron microscope (TEM) images, high resolution transmission electron microscope (HRTEM) images, selected area electron diffraction (SAED) patterns and energy dispersive X-ray spectroscopy (EDS) spectra were obtained with an FEI Talos F200A microscope (PSI, University of Manchester) equipped with an X-FEG electron source and Super-X SDD EDS detectors. The experiment was performed using an acceleration voltage of $200 \mathrm{kV}$ and a beam current of approximately $5 \mathrm{nA}$. Images were recorded with a FEI CETA $4 \mathrm{k} \times 4 \mathrm{k}$ CMOS camera. Single crystal X-ray data were collected on a dual source Rigaku FR-X rotating anode diffractometer using $\mathrm{Cu} \mathrm{K} \alpha$ wavelength at $150 \mathrm{~K}$ and reduced using CrysAlisPro 171.39.30c. Absorption correction was performed using empirical methods (SCALE3 ABSPACK) based upon symmetry-equivalent reflections combined with measurements at different azimuthal angles. The structure was solved and refined using Shelx-2016 implemented through Olex2 v1.2.9.2,3.

\section{Results and discussion}

\section{Characterization of the precursors}

The reaction of piperidine dithiocarbamate with $\mathrm{BiCl}_{3}$ and $\mathrm{SbCl}_{3}$ gave tris(piperidinedithiocarbamato)bismuth(III) $\left(\mathrm{Bi}\left(\mathrm{S}_{2}-\right.\right.$ $\left.\mathrm{CPip}_{3}\right)_{\text {(2) }}$ and tris(piperidinedithiocarbamato)antimony(III) $\left(\mathrm{Sb}\left(\mathrm{S}_{2} \mathrm{CPip}\right)_{3}\right)(3)$ respectively. The presence of the dithiocarbamate moiety in the two complexes was shown by the characteristic thioureide band $\nu(\mathrm{C}=\mathrm{N})$ around the $1450-1500 \mathrm{~cm}^{-1}$ region and the $\nu(\mathrm{C}=\mathrm{S})$ band around the $960-1000 \mathrm{~cm}^{-1}$. These bands appeared shifted to higher frequencies in the spectrum of the corresponding free ligand. The bidentate nature of the coordination of the dithiocarbamate ligand was shown by the band around $960-1000 \mathrm{~cm}^{-1}$ which appeared unsplit. ${ }^{40}$ Broad bands around $3300-3500 \mathrm{~cm}^{-1}$ in the spectra of the ligands as well as the antimony piperidine complex is due to the presence of moisture in the compounds.

Single crystals of complex (3) were grown in chloroform/ ethanol mixture, and their X-ray crystal structure was determined at $150 \mathrm{~K}$. The low temperature structure of tris(piperidinedithiocarbamato)antimony(III) $\left(\mathrm{Sb}\left(\mathrm{S}_{2} \mathrm{CPip}\right)_{3}\right)$, crystallizes into a six coordinate $\mathrm{Sb}$ complex surrounded by three piperidinedithiocarbamato groups bonded through $\mathrm{S}$ donor atoms. There are three short $\mathrm{Sb}-\mathrm{S}$ distances of $\sim 2.53 \AA$ and three long Sb-S distances of $\sim 2.9-3.0 \AA$. There is a stereochemically active lone pair on the $\mathrm{Sb}$ atom such that the (seven) steric groups (6 S donors and 1 lone pair) occupy the vertices of an 'elongated triangular pyramid' in which there are parallel triangular sets of $\mathrm{S}$ donors with the lone pair pointed normal to the planes of $3 \mathrm{~S}$ atoms (the short $\mathrm{Sb}-\mathrm{S}$ and the long $\mathrm{Sb}-\mathrm{S}$ ). A similar structure was reported by Liu and Tiekink ${ }^{\mathbf{4 1}}$ at a much higher temperature of $223 \mathrm{~K}$. The three short $\mathrm{Sb}-\mathrm{S}$ bond length was found to be $\sim 2.52 \AA$ and that of the three long Sb-S bonds were $2.86 \AA$, which favourably compares to those of complex (3). The mean interchelate $\mathrm{S}-\mathrm{Sb}-\mathrm{S}$ bond angles of 93.60 of complex (3) is also comparable to 92.32 of the reported structure. The crystal structure, some selected bond lengths together with the crystallographic data and structural refinement parameters for complex (3) are shown in ESI 2, 3 and 4 respectively. $\dagger$

The thermogram of complex (2) shows a three-step decomposition pattern. The first mass loss of $3.05 \%$ (2.56\% calculated) at $128{ }^{\circ} \mathrm{C}$ corresponds to the loss of $\mathrm{H}_{2} \mathrm{O}$ molecules. The second mass loss of $59.47 \%$ (58.56\% calculated) at $281{ }^{\circ} \mathrm{C}$ corresponds to the loss of the organic moiety and sulfur, while the third mass loss of $10.41 \%$ ( $11.09 \%$ calculated) at $464{ }^{\circ} \mathrm{C}$ is attributed to the additional loss of sulfur with the formation of a final residue of $33.67 \%$ (35.9\% calculated) corresponding to $\mathrm{Bi}_{2} \mathrm{~S}_{3}$. Complex (3) shows a two-step decomposition pattern, with the first mass loses of $8.68 \%$ (8.14\% calculated) at $100{ }^{\circ} \mathrm{C}$ corresponding to the loss of the three water molecules and a second mass loss of $70.49 \%$ ( $72.44 \%$ calculated) attributed to the loss of the organic moiety and sulfur with the formation of a residue of $26.16 \%$ (25.56\% calculated) which corresponds to $\mathrm{Sb}_{2} \mathrm{~S}_{3}$ (Fig. 1).

\section{Compositional characterization}

The EDX data (Fig. 2) (where the sampling depth is $\gg$ the nanorod diameter) shows that the composition of the particles synthesised is in close agreement with the mole fraction of precursors used. This result is unusual with single source precursors as the difference in metal-sulfur bond strengths normally governs the rate of decomposition and consequentially skews the composition to the more reactive metal-sulfur bond. A plot of $\mathrm{Sb}$ precursor mole fraction against the proportion of antimony in the particles gave a close to straight line (Fig. 2b) with full details in Table 1. Many of the samples were sulfur rich which is possibly due to the relatively low reaction temperature which prevented evaporation of sulfur, a situation commonly observed in samples prepared at a much higher temperature..$^{\mathbf{4 2 , 4 3}}$

The X-ray diffraction patterns obtained for all the $\mathrm{Bi} / \mathrm{Sb}$ ratios correspond well to the orthorhombic crystal system, with peaks for the $\mathrm{Bi}-\mathrm{Sb}-\mathrm{S}$ system falling between previously reported patterns of orthorhombic bismuthinite ${ }^{26}(a=11.2690 \AA, b=$ $3.9717 \AA$ and $c=11.1290 \AA$ ) and orthorhombic stibnite ${ }^{27}$ ( $a=$ $11.2990 \AA, b=3.8313 \AA$ and $c=11.2270 \AA$ ), Fig. $3 \mathrm{a} . \mathrm{Sb}_{2} \mathrm{~S}_{3}$ and

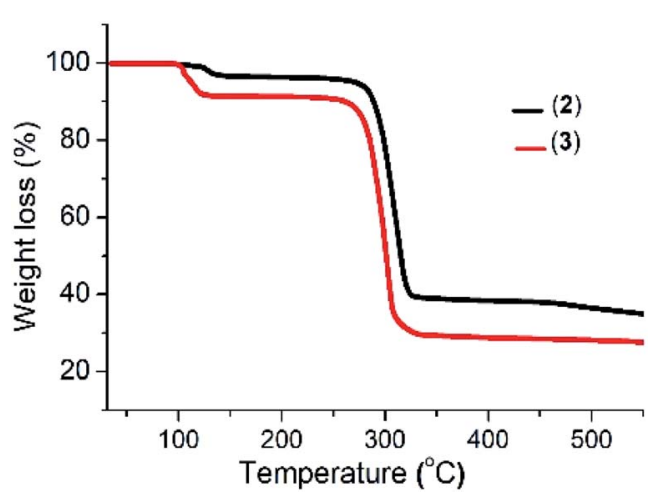

Fig. 1 Thermogram of complexes (2) and (3). 
(a)

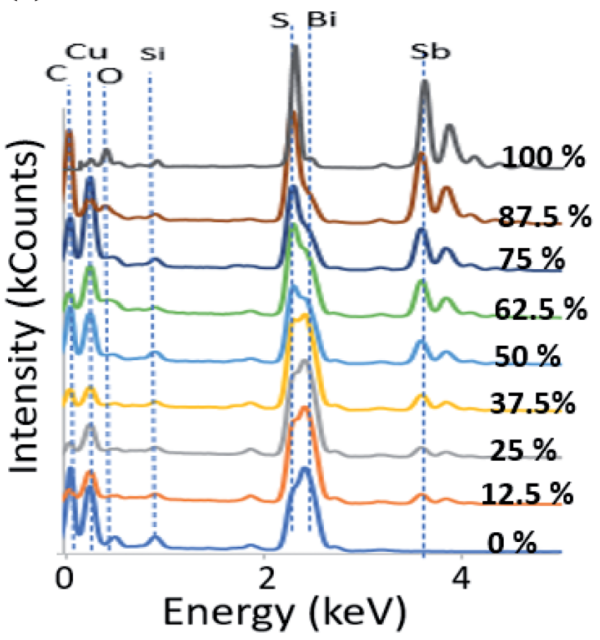

(b)

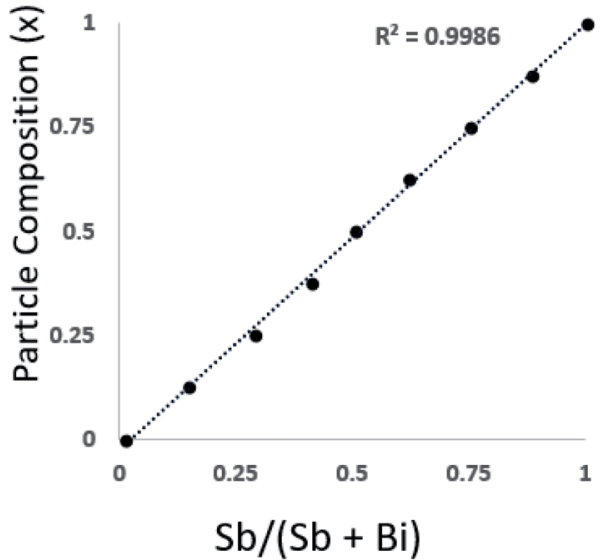

Fig. 2 (a) EDS spectra of $\left(\mathrm{Bi}_{1-x} \mathrm{Sb}_{x}\right)_{2} \mathrm{~S}_{3}$ nanorods at different $\mathrm{Bi}: \mathrm{Sb}$ mole ratios (b) particle composition $x$ obtained from EDS against precursor mole fraction.

Table 1 Structural data for $\mathrm{Bi}_{2} \mathrm{~S}_{3}, \mathrm{Sb}_{2} \mathrm{~S}_{3}$ and $\left(\mathrm{Bi}_{x} \mathrm{Sb}_{1-x}\right)_{2} \mathrm{~S}_{3}$ solid solution

\begin{tabular}{|c|c|c|c|c|c|c|}
\hline$X_{\mathrm{Bi}}(\%)$ & $X_{\mathrm{Sb}}(\%)$ & Chemical composition (EDX) & $a(\AA)$ & $b(\AA)$ & $c(\AA)$ & $V(\AA)^{3}$ \\
\hline 100.0 & 0.0 & $\mathrm{Bi}_{1.95} \mathrm{~S}_{3.05}$ & 11.24 & 3.97 & 11.13 & 496.68 \\
\hline 87.5 & 12.5 & $\mathrm{Sb}_{0.27} \mathrm{Bi}_{1.68} \mathrm{~S}_{3.05}$ & 11.24 & 3.95 & 11.14 & 494.32 \\
\hline 62.5 & 37.5 & $\mathrm{Sb}_{0.79} \mathrm{Bi}_{1.15} \mathrm{~S}_{3.06}$ & 11.25 & 3.92 & 11.16 & 491.88 \\
\hline 50.0 & 50.0 & $\mathrm{Sb}_{0.97} \mathrm{Bi}_{0.95} \mathrm{~S}_{3.08}$ & 11.26 & 3.91 & 11.19 & 492.00 \\
\hline 37.5 & 67.5 & $\mathrm{Sb}_{1.22} \mathrm{Bi}_{0.75} \mathrm{~S}_{3.04}$ & 11.26 & 3.87 & 11.19 & 487.13 \\
\hline 0.0 & 100.0 & $\mathrm{Sb}_{1.93} \mathrm{~S}_{3.07}$ & 11.27 & 3.82 & 11.22 & 483.22 \\
\hline
\end{tabular}

$\mathrm{Bi}_{2} \mathrm{~S}_{3}$ both crystallize in the same orthorhombic lattice system with a difference in cell volume of $3.5 \%$ due to $\mathrm{Sb}^{3+}$ possessing a smaller ionic radius than $\mathrm{Bi}^{3+}$. The enlarged portion of the XRD pattern of the samples show a shift in the peak position confirming the successful incorporation of $\mathrm{Sb}$ into the $\mathrm{Bi}_{2} \mathrm{~S}_{3}$ lattice and the movement through the entire compositional range of the $\left(\mathrm{Bi}_{1-x} \mathrm{Sb}_{x}\right)_{2} \mathrm{~S}_{3}$ solid solution, Fig. $3 \mathrm{~b}$. A plot of the dspacing for the (112) plane shows a gradual decrease from $\mathrm{Bi}_{2} \mathrm{~S}_{3}$ to the $\mathrm{Sb}_{2} \mathrm{~S}_{3}$ end with a percentage difference of $2.26 \%$ (ESI $5 \dagger$ ).

Refinement of the powder XRD data shows that all three axis of the unit cell vary linearly (Fig. 4). Upon increased incorporation of antimony, $a$ and $c$ increase whereas $b$ decreases which is the expected behaviour when moving between $\mathrm{Bi}_{2} \mathrm{~S}_{3}$ and $\mathrm{Sb}_{2} \mathrm{~S}_{3}$. All three cell parameters show a linear dependency on the amount of antimony in the solid solution which agrees with Vegard's law. The subtle deviations in $a$ and $c$ from ideal behaviour may be due to the contrasting effect of the stereochemical active lone pair of the $5 \mathrm{~s}^{2}$ and $6 \mathrm{~s}^{2}$ electrons of the antimony and bismuth atoms, which is positioned in the $a-c$ plane of the lattice. ${ }^{37,44}$ With an increased concentration of antimony, there is expansion of the inter-rod space due to the expression of the stereochemically active lone electron pair with a resulting expansion of the $a$ and $c$ parameters. ${ }^{30}$ However, the $b$ axis which is least affected by the stereochemical active lone pair experiences a continuous contraction on $\mathrm{Sb}$ substitution, probably due to decrease in the shortest $\mathrm{M}-\mathrm{S}$ bond as we move from the $\mathrm{Bi}_{2} \mathrm{~S}_{3}$ to the $\mathrm{Sb}_{2} \mathrm{~S}_{3}$ end. ${ }^{26}$ There is a general shrinkage of the overall cell volume of $\left(\mathrm{Bi}_{1-x^{-}}\right.$ $\left.\mathrm{Sb}_{x}\right)_{2} \mathrm{~S}_{3}$ as $\mathrm{Bi}$ is replaced by $\mathrm{Sb}$ (Fig. $4 \mathrm{~d}$ ).

The high-resolution transmission electron microscopy (HRTEM) images of the samples together with their selected area electron diffraction (SAED) patterns reveal the formation of highly polycrystalline powders showing two-dimensional lattice fringes (Fig. 4). Measured $d$-spacings of 3.69 and $4.98 \AA$ were obtained for pure $\mathrm{Bi}_{2} \mathrm{~S}_{3}$ (Fig. 5a) corresponding to the (011) and (102) planes (SG Pnma with $a=11.2690 \AA, b=3.9717 \AA$ and $c=$ $11.1290 \AA$ ) while for pure $\mathrm{Sb}_{2} \mathrm{~S}_{3}$ (Fig. 5i) a $d$-spacings of $3.50 \AA$ corresponding to the (111) (SG Pnma with $a=11.2990 \AA, b=$ $3.8313 \AA$ and $c=11.2270 \AA$ ) plane was recorded.

XPS is a much more surface sensitive technique than EDX, with sampling depths varying $6.3-9.0 \mathrm{~nm}$ for $\mathrm{Sb}, \mathrm{Bi}$ and $\mathrm{S},{ }^{45}$ which is much less than the nanorod diameter. Bi $4 \mathrm{f}$ coincides with the $\mathrm{S} 2 \mathrm{p}$ region, and $\mathrm{Sb} 3 \mathrm{~d}$ coincides with $\mathrm{O}$ 1s. Fig. 6 shows a pile-up of the $\mathrm{Bi} 4 \mathrm{f} / \mathrm{S} 2 \mathrm{p}$ and $\mathrm{Sb} 3 \mathrm{~d} / \mathrm{O} 1 \mathrm{~s}$ regions for $\mathrm{Bi}_{2} \mathrm{~S}_{3}, \mathrm{Sb}_{2} \mathrm{~S}_{3}$ and $\left(\mathrm{Bi}_{1-x} \mathrm{Sb}_{x}\right)_{2} \mathrm{~S}_{3}$. 

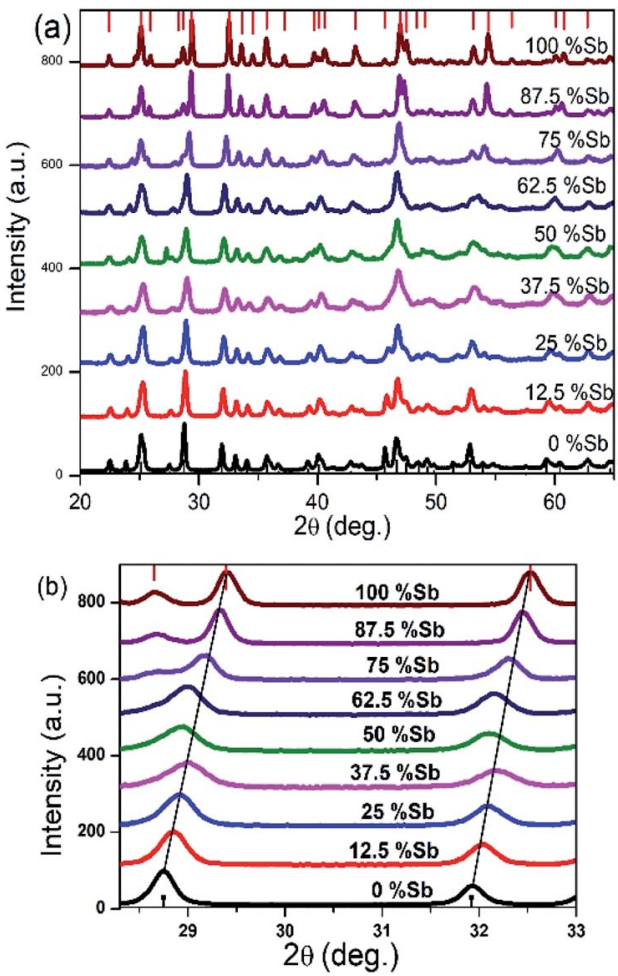

Fig. 3 (a) Powder XRD pattern of $\mathrm{Bi}_{2} \mathrm{~S}_{3}$ bottom, $\left(\mathrm{Bi}_{1-x} \mathrm{Sb}_{x}\right)_{2} \mathrm{~S}_{3}$ and $\mathrm{Sb}_{2} \mathrm{~S}_{3}$ top, samples synthesized from different $\mathrm{Bi} / \mathrm{Sb}$ ratios (b) $\mathrm{p}$-XRD pattern of $2 \theta$ range $27-33$ degree showing shift in peaks.

In all cases the Bi $4 \mathrm{f}$ doublet required two chemical species (two sets of spin-orbit-split doublets) in order to obtain an adequate fit, with positions for the $\mathrm{Bi} 4 \mathrm{f}_{7 / 2}$ photoelectron peaks at $158.1 \mathrm{eV}$ (associated with $\mathrm{Bi}_{2} \mathrm{~S}_{3}{ }^{46}$ and $158.8 \mathrm{eV}$ (associated with oxidized $\mathrm{Bi}_{2} \mathrm{O}_{3}{ }^{47}$ Likewise, the $\mathrm{Sb}$ 3d doublet required two chemical species for adequate fitting, with peak positions for $3 \mathrm{~d}_{5 /}$ ${ }_{2}$ at $259.1 \mathrm{eV}$ (associated with $\mathrm{Sb}_{2} \mathrm{~S}_{3}{ }^{48}$ and $530.1 \mathrm{eV}$ (associated with oxidized $\left.\mathrm{Sb}_{2} \mathrm{O}_{3}\right){ }^{49}$ Note that $\mathrm{O}$ 1s photoelectron peaks are
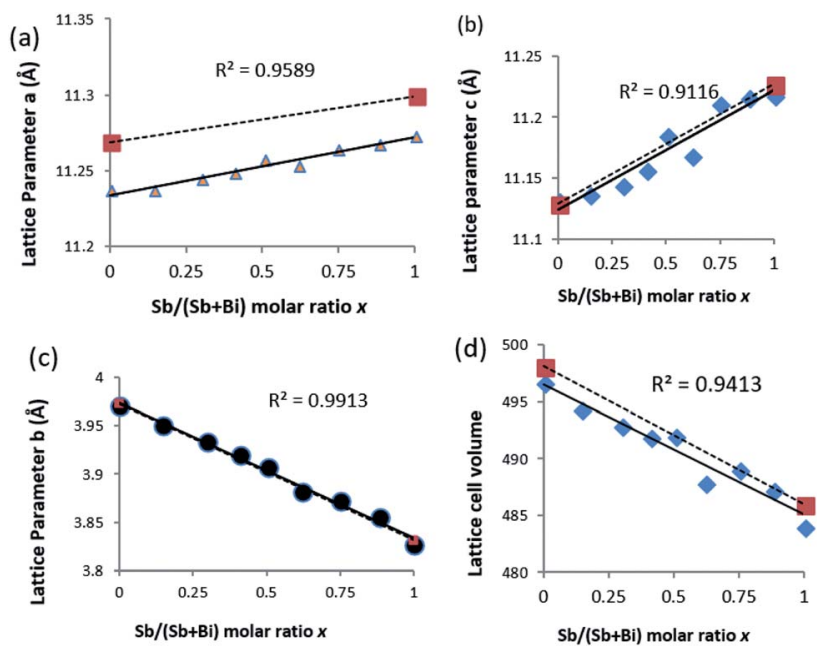

Fig. 4 Variation of lattice constants with increasing mole fraction of $\mathrm{Sb}$ obtained from EDS. (a) Lattice parameter $a$, (b) lattice parameter b, (c) lattice parameter $c$ and $(d)$ cell volume. * values represent the reported standard value (dotted lines) for $\mathrm{Bi}_{2} \mathrm{~S}_{3}$ and $\mathrm{Sb}_{2} \mathrm{~S}_{3}$.
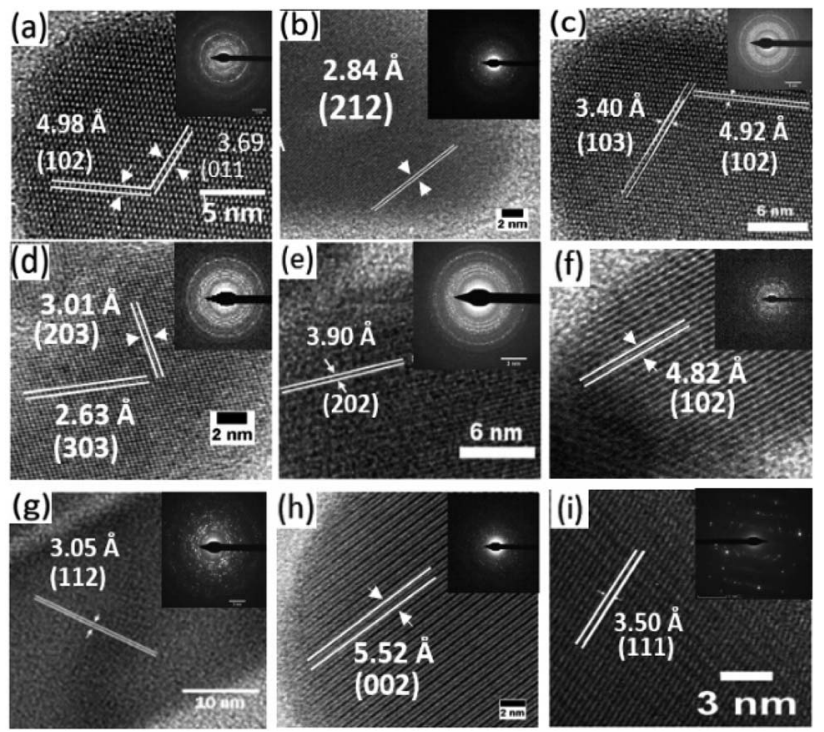

Fig. 5 HRTEM images of synthesized nanorods with $\mathrm{Sb} /(\mathrm{Sb}+\mathrm{Bi})$ mole fraction of (a) $1: 0$, (b) $7: 1$, (c) $3: 1$, (d) $5: 3$, (e) $1: 1$, (f) $3: 5$, (g) $1: 3$, (h) $1: 7$ and (i) $0: 1$. Inset in each image shows the SAED pattern.

close to the $\mathrm{Sb}_{3} \mathrm{~d}_{5 / 2}$ signal, typically with binding energy positions at $\sim 530.5 \mathrm{eV}$ associated with metal oxides (i.e., $\mathrm{BiO}_{x}, \mathrm{SbO}_{x}$ ), $\sim 532 \mathrm{eV}$ associated with $\mathrm{C}-\mathrm{O}$ contamination, and $\sim 533 \mathrm{eV}$ associated with $\mathrm{C}=\mathrm{O}$ contamination. A variety of $\left(\mathrm{Bi}_{x} \mathrm{Sb}_{1-x}\right)_{2} \mathrm{~S}_{3}$ samples were measured, and consistently a peak-fitting model including sulfide and oxide species was required for both $\mathrm{Bi}$ and $\mathrm{Sb}$. However, no oxidation was seen for S, only one species for the $\mathrm{S} 2 \mathrm{p}$ doublet was observed for all the samples measured, with the peak position for $2 \mathrm{p}_{3 / 2}$ at $\sim 161.0 \mathrm{eV}$ associated with sulfide, ${ }^{46,48}$ and in the spectra there is a clear absence of any signal associated with sulfate which is expected in the binding energy region 168$170 \mathrm{eV} .^{50}$ Also, when calculating the atomic ratios of $\mathrm{Bi}: \mathrm{Sb}: \mathrm{S}$, there is consistently an absence of $\mathrm{S}$ as expected for $\left(\mathrm{Bi}_{1-x} \mathrm{Sb}_{x}\right)_{2} \mathrm{~S}_{3}$. In Fig. 6 the $\left(\mathrm{Bi}_{x} \mathrm{Sb}_{1-x}\right)_{2} \mathrm{~S}_{3}$ sample exhibits a $\mathrm{Bi}: \mathrm{Sb}: \mathrm{S}$ ratio of $3: 3: 4$ (or $1: 1: 1.3$, short of the expected $1: 1: 1.5$ ). This indicates that there is an absence of sulfur atoms at the surface of

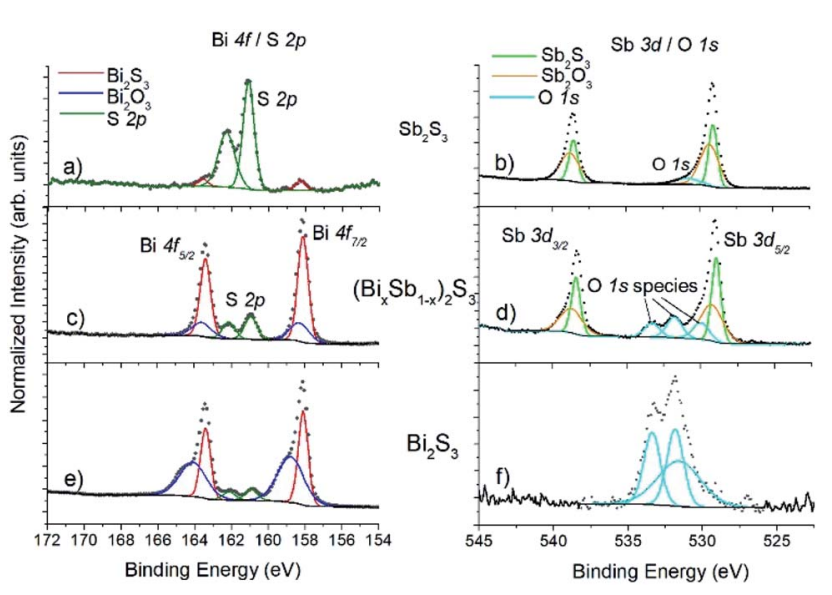

Fig. 6 XPS spectra for $\mathrm{Sb}_{2} \mathrm{~S}_{3}$ (top panels (a) and (b)), $\mathrm{Bi}_{2} \mathrm{~S}_{3}$ (bottom panels (e) and (f)), and $\left(\mathrm{Bi}_{x} \mathrm{Sb}_{1-x}\right)_{2} \mathrm{~S}_{3}$ (middle panels (c) and (d)). The Bi $4 \mathrm{f}$ and $S 2 p$ spectral regions overlap ((a), (c), (e)), and the Sb $3 d$ region overlaps with $\mathrm{O} 1 \mathrm{~s}((\mathrm{~b}),(\mathrm{d}),(\mathrm{f}))$. 
the nanorods hence the atomic concentrations (Table 2) are skewed from the bulk measurement by EDX analysis. This also explains the lack of sulfur oxidation while a small amount of Bi and $\mathrm{Sb}$ atoms at the surface of the nanorods are susceptible to oxidation. For the range of $\left(\mathrm{Bi}_{1-x} \mathrm{Sb}_{x}\right)_{2} \mathrm{~S}_{3}$ nanorod materials measured, the amount of oxidation of $\mathrm{Bi}$ and $\mathrm{Sb}$ observed varied between $10-40 \%$ (with an average value of $20 \%$ for $\mathrm{Bi}$ and $26 \%$ for $\mathrm{Sb})$.

\section{Morphological characterization}

TEM analysis on the samples showed the presence of particles with a rod-shaped morphology, Fig. 7a-i. When the bismuth precursor was exclusively used, uniform elongated cylindrical nanorods of $\mathrm{Bi}_{2} \mathrm{~S}_{3}$ were obtained however the antimony precursor gave long sheaf-like collections of $\mathrm{Sb}_{2} \mathrm{~S}_{3}$ rods in the sub-micrometre range (Fig. $7 \mathrm{i}$ and $8 \mathrm{e}$ ).
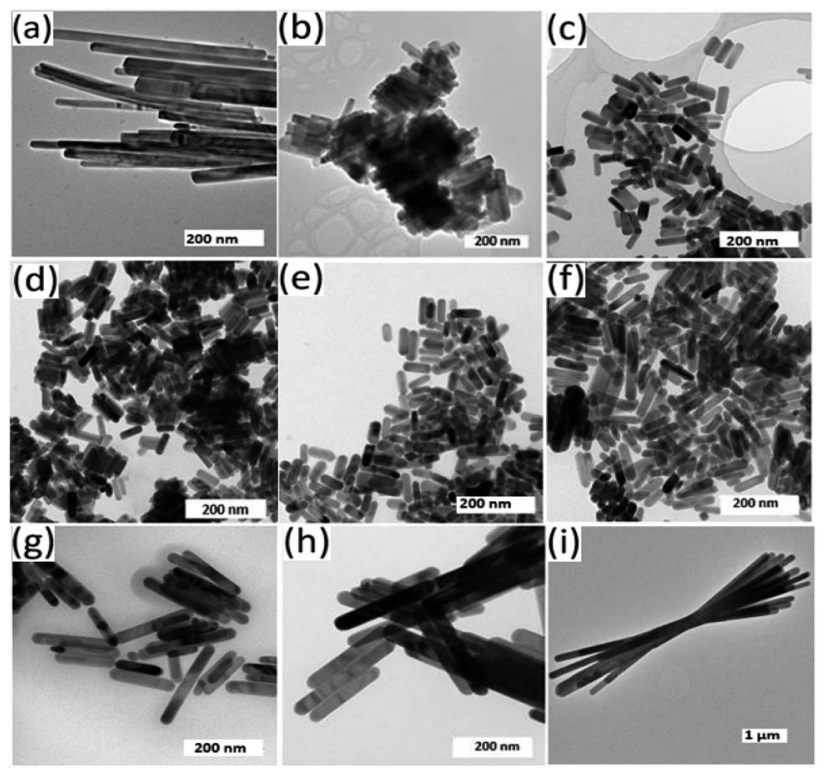

(e)
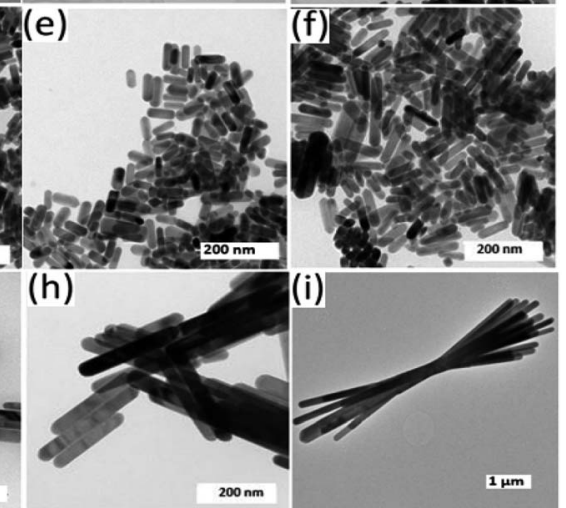

Fig. 7 TEM images showing the as synthesized nanorods with $\mathrm{Bi}: \mathrm{Sb}$ mole ratios of (a) $1: 0$, (b) $7: 1$, (c) $3: 1$, (d) $5: 3$, (e) $1: 1$, (f) $3: 5$, (g) $1: 3$, (h) $1: 7$ and (i) $0: 1$.
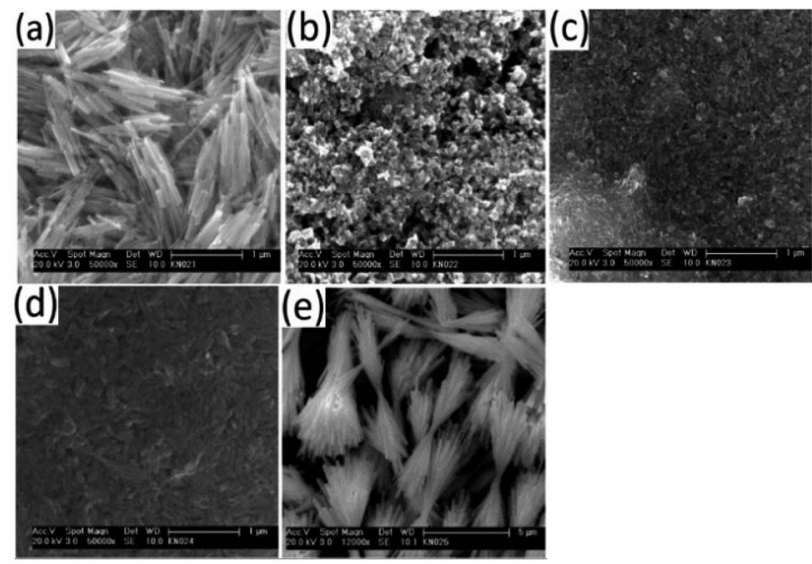

Fig. 8 SEM images showing surface scan of films with $\mathrm{Bi}: \mathrm{Sb}$ mole ratios of (a) $1: 0$, (b) $3: 1$, (c) $1: 1$, (d) $1: 3$, (e) $0: 1$.
There was a conspicuous change in the aspect ratio of the rods as the $\mathrm{Bi}: \mathrm{Sb}$ precursor mole ratio was varied, Table 3. With a $\mathrm{Bi}: \mathrm{Sb}$ precursor mole ratio of $7: 1$, there was a considerable reduction in both the length and aspect ratio of the nanorods compared to pure $\mathrm{Bi}_{2} \mathrm{~S}_{3}$ until a mole ratio of $1: 1$, which gave an aspect ratio of 2.58 (Table 3). Wang et al. prepared $\left(\mathrm{Bi}_{1-x} \mathrm{Sb}_{x}\right)_{2} \mathrm{~S}_{3}$ 1-d rods, by reacting bismuth chloride, antimony chloride, sulphur powder, oleylamine and thiols and observed composition dependant aspect ratios. ${ }^{1}$ Sun et al. synthesized flower-like architectures $\mathrm{Sb}_{2-x} \mathrm{Bi}_{x} \mathrm{~S}_{3}$ by solvothermal treatment of bismuth and antimony diethyldithiocarbamate complexes. They proposed a mechanism in which 3-d flowers grow through an epitaxial growth on $\mathrm{Sb}_{2-x}$ $\mathrm{Bi}_{x} \mathrm{~S}_{3}$ core. ${ }^{51}$ When we increased the precursor mole ratio of $\mathrm{Sb}$ beyond $1: 1$, the aspect ratio increased along with the length of the rods. At a mole ratio of $1: 7$ the longest rods of the solid solution were observed. $\mathrm{Sb}_{2} \mathrm{~S}_{3}$ has a partial fractal splitting growth habit which often lead to the formation of sheaf-like morphologies. ${ }^{52}$ However, the inclusion of $\mathrm{Bi}$ ions alters the growth dynamics by inducing complete splitting growth and consequently changes morphology from very long sheaf-like sub-micrometre $\mathrm{Sb}_{2} \mathrm{~S}_{3}$ rods to shorter separate nanorods. The particle size distribution of the as synthesized nanorods are shown in ESI $6 . \dagger$ TEM images of intermediate $\mathrm{Bi}: \mathrm{Sb}$ ratio to those reported are shown in ESI 7. $\dagger$

Table 2 Relative percentage concentrations of $\mathrm{Bi}, \mathrm{Sb}$ and $\mathrm{S}$ for $\mathrm{Bi}_{2} \mathrm{~S}_{3}$, $\mathrm{Sb}_{2} \mathrm{~S}_{3}$ and $\left(\mathrm{Bi}_{1-x} \mathrm{Sb}_{x}\right)_{2} \mathrm{~S}_{3}$. Bi and $\mathrm{Sb}$ are further delineated into sulfide and oxide species, where oxidation occurs between $10-40 \%$ of the time (with an average of $20 \%$ for $\mathrm{Bi}$ and $26 \%$ for $\mathrm{Sb}$ )

$\mathrm{Sb} /(\mathrm{Sb}+\mathrm{Bi}) \mathrm{Bi}-\mathrm{S} \% \mathrm{Bi}-\mathrm{O} \%$ Total $\mathrm{Bi} \% \mathrm{Sb}-\mathrm{S} \% \mathrm{Sb}-\mathrm{O} \%$ Total $\mathrm{Sb} \% \mathrm{~S} \%$

$\begin{array}{lrrrrrrr}0 & 49.79 & 18.69 & 68.49 & 0.00 & 0.00 & 0.00 & 31.51 \\ 0.125 & 49.11 & 9.33 & 58.43 & 4.44 & 0.49 & 4.93 & 36.64 \\ 0.25 & 45.20 & 8.61 & 53.81 & 7.86 & 1.56 & 9.43 & 36.76 \\ 0.375 & 37.32 & 8.25 & 45.57 & 17.53 & 1.76 & 19.29 & 35.14 \\ 0.5 & 34.86 & 5.81 & 40.67 & 15.55 & 6.17 & 21.72 & 37.60 \\ 0.625 & 27.85 & 5.32 & 33.17 & 20.94 & 7.39 & 28.34 & 38.49 \\ 0.75 & 27.45 & 3.40 & 30.85 & 23.36 & 6.67 & 30.03 & 39.13 \\ 0.875 & 17.09 & 1.66 & 18.74 & 29.75 & 11.16 & 40.91 & 40.35 \\ 1 & 3.56 & 0.00 & 3.56 & 38.20 & 12.14 & 50.34 & 46.10\end{array}$

Table 3 Dimensions of synthesised nanorods of $\mathrm{Bi}_{2} \mathrm{~S}_{3}, \mathrm{Sb}_{2} \mathrm{~S}_{3}$ and $\left(\mathrm{Bi}_{1-x} \mathrm{Sb}_{x}\right)_{2} \mathrm{~S}_{3}$ solid solution

\begin{tabular}{lccr}
\hline $\mathrm{Sb} /(\mathrm{Sb}+\mathrm{Bi})$ & Length $(\mathrm{nm})$ & Width $(\mathrm{nm})$ & $\begin{array}{l}\text { Aspect } \\
\text { ratio }\end{array}$ \\
\hline 0 & $474.4 \pm 92.62$ & $28.61 \pm 12.90$ & 16.58 \\
0.125 & $104.99 \pm 46.38$ & $19.79 \pm 9.13$ & 5.31 \\
0.25 & $65.13 \pm 13.52$ & $23.69 \pm 6.50$ & 2.75 \\
0.375 & $57.00 \pm 11.12$ & $15.55 \pm 4.07$ & 3.66 \\
0.5 & $60.38 \pm 12.60$ & $23.38 \pm 4.38$ & 2.58 \\
0.625 & $25.04 \pm 7.37$ & $5.56 \pm 1.09$ & 4.51 \\
0.75 & $142.81 \pm 56.58$ & $28.56 \pm 5.01$ & 5.00 \\
0.875 & $386.32 \pm 137.43$ & $40.05 \pm 11.08$ & 9.65 \\
1 & $2880.47 \pm 550.22$ & $137.09 \pm 44.82$ & 21.01
\end{tabular}




\section{Optical properties}

$\mathrm{Bi}_{2} \mathrm{~S}_{3}$ and $\mathrm{Sb}_{2} \mathrm{~S}_{3}$ possess direct band gaps of approximately 1.3 and $1.7 \mathrm{eV}$ respectively, corresponding to 954 and $729 \mathrm{~nm}$. The band gap of the ternary $\left(\mathrm{Bi}_{1-x} \mathrm{Sb}_{x}\right)_{2} \mathrm{~S}_{3}$ solid solutions made using different ratios of $\mathrm{Bi}$ and $\mathrm{Sb}$ should be a linear interpolation of the two parent materials. Fig. 9a shows the UV-visible absorption spectra of the as-prepared ternary $\left(\mathrm{Bi}_{1-x} \mathrm{Sb}_{x}\right)_{2} \mathrm{~S}_{3}$ in which a strong broad absorption was seen within the wavelength range of 300-1100 nm. In general, the absorption edge of $\left(\mathrm{Bi}_{1-x} \mathrm{Sb}_{x}\right)_{2} \mathrm{~S}_{3}$ nanorods is blue-shifted with the increase of $\mathrm{Sb}$ ratio.

However, a plot of the absorption maximum against the antimony mole fraction shows a marked deviation from the expected linear behaviour of the band gap of ternary semiconductor materials (Fig. 10). This phenomenon known as band gap bowing is often ascribed to local compositional fluctuations which occur on substitution. The extent of such local atom displacements usually brings about nonlinear dependence on optical properties in ternary materials. ${ }^{44,53}$ O'Brien et al. synthesize $\mathrm{Bi}_{2-2 x} \mathrm{Sb}_{2 x} \mathrm{~S}_{3}$ solid solutions from solvent less thermolysis of metal xanthate precursors and showed a slight deviation from linearity in the energy band gap on Sb substitution due to stoichiometric variations in the synthesized solid solution. $^{54}$

The Raman spectra of the particles are shown in Fig. 11. In case of pure $\mathrm{Bi}_{2} \mathrm{~S}_{3}$ sample, a minor peak was observed at $184 \mathrm{~cm}^{-1}$ and two prominent peaks at 236 and $256 \mathrm{~cm}^{-1}$, which is in agreement with the previously reported Raman data for $\mathrm{Bi}_{2} \mathrm{~S}_{3}$. The minor peak is assigned as $\mathrm{A}_{\mathrm{g}}$ symmetric bending mode, whereas the dominant peaks (236 and $256 \mathrm{~cm}^{-1}$ ) are $A_{g}$ and $\mathrm{B}_{1 \mathrm{~g}}$ anti-symmetric stretching modes, respectively. ${ }^{55,56}$ Similarly, one minor and two major peaks at 186, 272 and $294 \mathrm{~cm}^{-1}$ were observed for pure $\mathrm{Sb}_{2} \mathrm{~S}_{3}$, which are in good agreement with the previous reports. ${ }^{57-59}$ The peak at $186 \mathrm{~cm}^{-1}$ can be assigned to the $\mathrm{B}_{1 \mathrm{~g}}$ anti-symmetric $\mathrm{S}-\mathrm{Sb}-\mathrm{S}$ bending modes, whereas the peaks at 272 and $294 \mathrm{~cm}^{-1}$ are assigned to the $\mathrm{A}_{\mathrm{g}}$ and $\mathrm{B}_{1 \mathrm{~g}}$ anti-symmetric $\mathrm{Sb}-\mathrm{S}$ stretching modes, respectively. ${ }^{56,57}$ The solid solutions consisting of $25 \%$ antimony show mainly one broad band around $240 \mathrm{~cm}^{-1}$, which shift to higher frequencies of 253 and $260 \mathrm{~cm}^{-1}$ when the percentage of
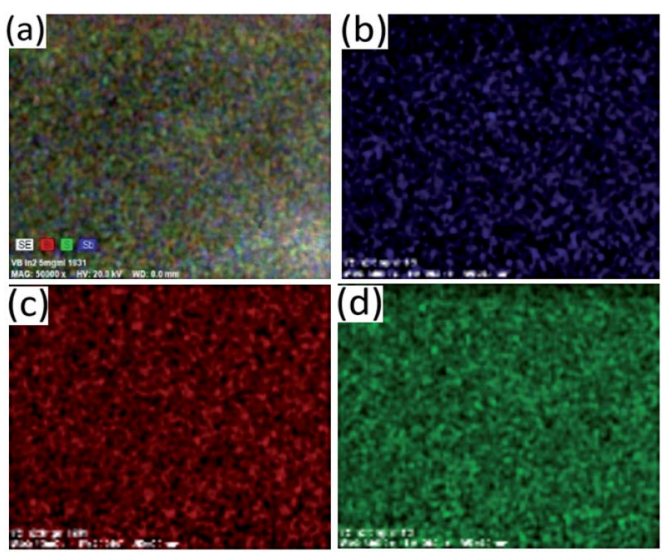

Fig. 9 Elemental mapping of the particles synthesized at $\mathrm{Bi}: \mathrm{Sb}$ mole ratio of 1 : 1 showing distribution of atoms (a) SE, (b) Sb, (c) Bi and (d) S.
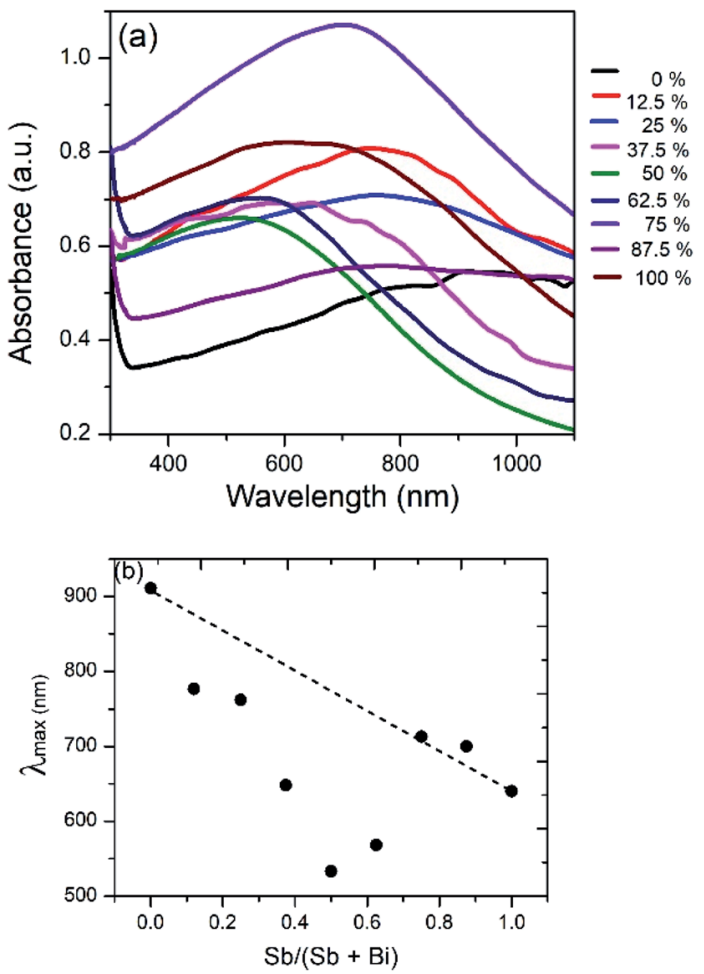

Fig. 10 (a) UV/visible absorption spectrum of $\mathrm{Bi}_{2} \mathrm{~S}_{3}, \mathrm{Sb}_{2} \mathrm{~S}_{3}$ and $\left(\mathrm{Bi}_{1-x^{-}}\right.$ $\left.\mathrm{Sb}_{x}\right)_{2} \mathrm{~S}_{3}$ solid solutions. (b) Plot of absorption maximum against mole fraction of $\mathrm{Sb}$, showing deviation from ideal behaviour.

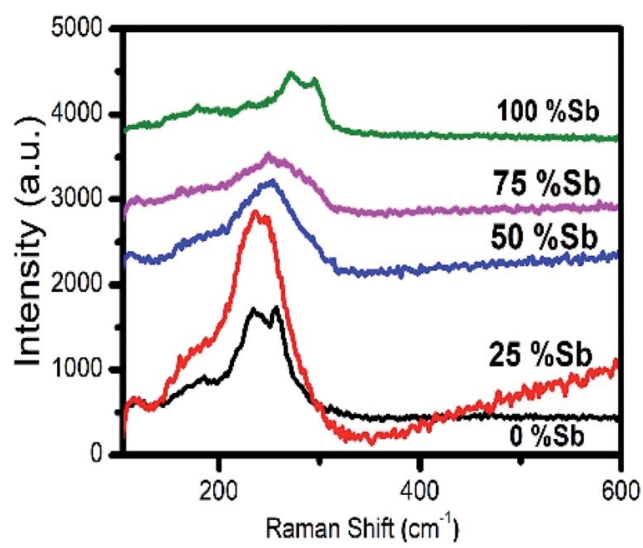

Fig. 11 Raman spectra of nanorods of $\mathrm{Sb}_{2} \mathrm{~S}_{3}, \mathrm{Bi}_{2} \mathrm{~S}_{3}$ and $\left(\mathrm{Bi}_{1-x} \mathrm{Sb}_{x}\right)_{2} \mathrm{~S}_{3}$ solid solutions.

antimony is increased to 50 and $75 \%$ respectively. The shift towards the higher wavenumber is due to lower mass of $\mathrm{Sb}$ as compare to $\mathrm{Bi}$ and shorter $\mathrm{Sb}-\mathrm{S}$ bond respectively. ${ }^{\mathbf{6 0 , 6 1}}$

\section{Conclusions}

By the thermal decomposition of bismuth and antimony piperidinedithiocarbamates in oleylamine nanorods of the entire compositional range of $\left(\mathrm{Bi}_{1-x} \mathrm{Sb}_{x}\right)_{2} \mathrm{~S}_{3}$ of solid solutions have been produced by varying the bismuth and antimony precursor mole fraction. The morphologies of the nanorods 
depended on their compositions, and aspect ratios that decreased to a minimum of 2.58 with maxima of 16.58 when using just the bismuth precursor and 21.01 when using the antimony precursor.

The XRD peaks at all ratios correspond to the orthorhombic crystals system and fall between those of orthorhombic $\mathrm{Bi}_{2} \mathrm{~S}_{3}$ and orthorhombic $\mathrm{Sb}_{2} \mathrm{~S}_{3}$. The gradual shift in the peaks position in combination with compositional data from EDX confirms the successful incorporation of antimony into bismuth sulphide which almost adheres to Vegard's law.

\section{Conflicts of interest}

There are no conflicts to declare.

\section{Acknowledgements}

The authors thank the Royal Society-Department for International Development (RS-DFID) for their financial support. NR acknowledges the National Research Foundation (NRF), South Africa through the South African Research Chair Initiative (SARChI) for financial support. We thank Dr George Whiteheard of the X-ray crystallography unit, School of Chemistry of the University of Manchester for the X-ray crystal structure of complex (3).

\section{References}

1 J. Wang, H. Yu, T. Wang, Y. Qiao, Y. Feng and K. Chen, ACS Appl. Mater. Interfaces, 2018, 10, 7334-7343.

2 D. Mocatta, G. Cohen, J. Schattner, O. Millo, E. Rabani and U. Banin, Science, 2011, 332, 77-81.

3 H.-Y. Chen, S. Maiti and D. H. Son, ACS Nano, 2012, 6, 583591.

4 B. K. Patra, S. Khilari, A. Bera, S. K. Mehetor, D. Pradhan and N. Pradhan, Chem. Mater., 2017, 29, 1116-1126.

5 V. V. Killedar, C. D. Lokhande and C. H. Bhosale, Thin Solid Films, 1996, 289, 14-16.

6 B. Yang, D.-J. Xue, M. Leng, J. Zhong, L. Wang, H. Song, Y. Zhou and J. Tang, Sci. Rep., 2015, 5, DOI: 10.1038/ srep10978.

7 F. Caruso, M. R. Filip and F. Giustino, Phys. Rev. B: Condens. Matter Mater. Phys., 2015, 92, DOI: 10.1103/ PhysRevB.92.125134.

8 A. Hussain, A. Begum and A. Rahman, Mater. Sci. Semicond. Process., 2014, 21, 74-81.

9 O. C. Monteiro, H. I. S. Nogueira, T. Trindade and M. Motevalli, Chem. Mater., 2001, 13, 2103-2111.

10 B. B. Nayak, H. N. Acharya, G. B. Mitra and B. K. Mathur, Thin Solid Films, 1983, 105, 17-24.

11 G. Konstantatos, L. Levina, J. Tang and E. H. Sargent, Nano Lett., 2008, 8, 4002-4006.

12 M. Bernechea, Y. Cao and G. Konstantatos, J. Mater. Chem. A, 2015, 3, 20642-20648.

13 W. Lou, M. Chen, X. Wang and W. Liu, Chem. Mater., 2007, 19, 872-878.
14 J. B. Biswal, N. V. Sawant and S. S. Garje, Thin Solid Films, 2010, 518, 3164-3168.

15 L. P. Deshmukh, J. Electrochem. Soc., 1994, 141, 1779.

16 X. Xiong, G. Wang, Y. Lin, Y. Wang, X. Ou, F. Zheng, C. Yang, J.-H. Wang and M. Liu, ACS Nano, 2016, 10, 10953-10959.

17 D. Y. W. Yu, P. V. Prikhodchenko, C. W. Mason, S. K. Batabyal, J. Gun, S. Sladkevich, A. G. Medvedev and O. Lev, Nat. Commun., 2013, 4, DOI: 10.1038/ncomms3922.

18 K. Ramasamy, H. Sims, W. H. Butler and A. Gupta, J. Am. Chem. Soc., 2014, 136, 1587-1598.

19 S. Sarkar, A. K. Guria, B. K. Patra and N. Pradhan, Angew. Chem., Int. Ed., 2014, 12566-12570.

20 G. Manna, R. Bose and N. Pradhan, Angew. Chem., Int. Ed., 2014, 53, 6743-6746.

21 J. Ma, Y. Wang, Y. Wang, Q. Chen, J. Lian and W. Zheng, J. Phys. Chem. C, 2009, 113, 13588-13592.

22 S. Yao, J. Cui, Z. Lu, Z.-L. Xu, L. Qin, J. Huang, Z. Sadighi, F. Ciucci and J.-K. Kim, Adv. Energy Mater., 2017, 7, 1602149.

23 K. Zhang, T. Luo, H. Chen, Z. Lou and G. Shen, J. Mater. Chem. C, 2017, 5, 3330-3335.

24 X. Wang, R. Tang, C. Wu, C. Zhu and T. Chen, J. Energy Chem., 2018, 27, 713-721.

25 V. W. Lueth, P. C. Goodell and N. E. Pngitore, Econ. Geol., 1990, 85, 1462-1472.

26 D. Poleti, L. Karanović, T. Balić-Žunić and I. Gržetić, Neues Jahrb. Mineral., Abh., 2012, 189, 177-187.

27 L. F. Lundegaard, R. Miletich, T. Balic-Zunic and E. Makovicky, Phys. Chem. Miner., 2003, 30, 463-468.

28 L. F. Lundegaard, E. Makovicky, T. Boffa-Ballaran and T. Balic-Zunic, Phys. Chem. Miner., 2005, 32, 578-584.

29 M. R. Filip, C. E. Patrick and F. Giustino, Phys. Rev. B: Condens. Matter Mater. Phys., 2013, 87, DOI: 10.1103/ PhysRevB.87.205125.

30 A. Kyono and M. Kimata, Am. Mineral., 2004, 89, 932-940.

31 J. Liu, J. Liu, J. Li, H. Xie, J. Wang, J. Deng, C. Feng, F. Qi and N. Zhang, Int. Geol. Rev., 2008, 50, 163-176.

32 G. Springer, Mineral. Mag., 1969, 37, 294.

33 P. S. Nair, T. Radhakrishnan, N. Revaprasadu, G. A. Kolawole and P. O'Brien, Chem. Commun., 2002, 564-565.

34 S. Ghosal and R. O. Sack, Mineral. Mag., 1999, 63, 723-733. 35 J. Chang and E. R. Waclawik, RSC Adv., 2014, 4, 2350523527.

36 A. V. Nikam, B. L. V. Prasad and A. A. Kulkarni, CrystEngComm, 2018, 20, 5091-5107.

37 M. Leszczynski, E. Litwin-Staszewska and T. Suski, Acta Phys. Pol., A, 1995, 88, 837-840.

38 M. D. Khan, M. Aamir, G. Murtaza, M. A. Malik and N. Revaprasadu, Dalton Trans., 2018, 47, 10025-10034.

39 W. N. Kun, S. Mlowe, L. D. Nyamen, P. T. Ndifon, M. A. Malik, O. Q. Munro and N. Revaprasadu, Chem.-Eur. J., 2016, 22, 13127-13135.

40 R. Kellner, G. St. Nikolov and N. Trendafilova, Inorg. Chim. Acta, 1984, 84, 233-239.

41 Y. Liu and E. R. T. Tiekink, CrystEngComm, 2005, 7, 20.

42 L. Chen, H. Deng, J. Cui, J. Tao, W. Zhou, H. Cao, L. Sun, P. Yang and J. Chu, J. Alloys Compd., 2015, 627, 388-392. 
43 J. He, L. Sun, K. Zhang, W. Wang, J. Jiang, Y. Chen, P. Yang and J. Chu, Appl. Surf. Sci., 2013, 264, 133-138.

44 R. A. Groom, A. Jacobs, M. Cepeda, R. Drummey and S. E. Latturner, Inorg. Chem., 2017, 56, 12362-12368.

45 S. Tanuma, C. J. Powell and D. R. Penn, Surf. Interface Anal., 1994, 21, 165-176.

46 J. Grigas, E. Talik and V. Lazauskas, Phys. Status Solidi B, 2002, 232, 220-230.

47 K. Uchida and A. Ayame, Surf. Sci., 1996, 357-358, 170-175.

48 V. P. Zakaznova-Herzog, S. L. Harmer, H. W. Nesbitt, G. M. Bancroft, R. Flemming and A. R. Pratt, Surf. Sci., 2006, 600, 348-356.

49 C. D. Wagner, Faraday Discuss. Chem. Soc., 1975, 60, 291.

50 A. A. Audi and P. M. A. Sherwood, Surf. Interface Anal., 2000, 29, 265-275.

51 J. Sun, X. Shen, L. Guo, G. Wang, J. Park and K. Wang, Nanoscale Res. Lett., 2010, 5, 364-369.

52 J. Wang, Y. Qiao, T. Wang, H. Yu, Y. Feng and J. Zhang, CrystEngComm, 2019, 21, 554-562.
53 M. J. Seong, H. Alawadhi, I. Miotkowski, A. K. Ramdas and S. Miotkowska, Solid State Commun., 1999, 112, 329-334.

54 T. Alqahtani, M. D. Khan, D. J. Kelly, S. J. Haigh, D. J. Lewis and P. O'Brien, J. Mater. Chem. C, 2018, 6, 12652-12659.

55 V. Kaltenhauser, T. Rath, W. Haas, A. Torvisco, S. K. Müller, B. Friedel, B. Kunert, R. Saf, F. Hofer and G. Trimmel, J. Mater. Chem. C, 2013, 1, 7825.

56 S. Kharbish, E. Libowitzky and A. Beran, Eur. J. Mineral., 2009, 21, 325-333.

57 M. Medles, N. Benramdane, A. Bouzidi, K. Sahraou, R. Miloua, R. Desfeux and C. Mathie, J. Optoelectron. Adv. Mater., 2014, 16, 726-731.

58 G. Wang and C. L. Cheung, Mater. Lett., 2012, 67, 222-225.

59 J. Ota, P. Roy, S. K. Srivastava, B. B. Nayak and A. K. Saxena, Cryst. Growth Des., 2008, 8, 2019-2023.

60 I. Zumeta-Dubé, J.-L. Ortiz-Quiñonez, D. Díaz, C. TralleroGiner and V.-F. Ruiz-Ruiz, J. Phys. Chem. C, 2014, 118, 30244-30252.

61 B. Minceva-Sukarova, M. Najdoski, I. Grozdanov and C. J. Chunnilall, J. Mol. Struct., 1997, 410-411, 267-270. 